\title{
A UTILIZAÇÃO DE BANCOS DE PERFIS GENÉTICOS PARA FINS CRIMINAIS: ANTIGOS E NOVOS DILEMAS NO CENÁRIO DA NECROPOLÍTICA BRASILEIRA
}

\section{THE USE OF DNA DATABASES IN CRIMINAL PROSECUTION: OLD AND NEW DILEMMAS IN THE SCENARIO OF BRAZILIAN NECROPOLITICS}

\author{
Recebimento: 11 jun. 2020 \\ Aceitação: 17 maio 2021 \\ Clara Maria Roman Borges \\ Doutora em Direito \\ Afiliação institucional: Universidade Federal do Paraná - UFPR - (Curitiba, PR, Brasil) \\ Lattes iD: http://lattes.cnpq.br/2956229202316120 \\ Email: romanborges@uol.com.br \\ Deise dos Santos Nascimento \\ Mestra em Direito \\ Afiliação institucional: Universidade Federal do Paraná - UFPR - (Curitiba, PR, Brasil) \\ Lattes iD: http://lattes.cnpq.br/9346936861351987 \\ Email:deise.sn@outlook.com
}

Como citar este artigo / How to cite this article (informe a data atual de acesso / inform the current date of access):

BORGES, Clara Maria Roman; NASCIMENTO, Deise dos Santos. A utilização de bancos de perfis genéticos para fins criminais: antigos e novos dilemas no cenário da necropolítica brasileira. Revista da Faculdade de Direito UFPR, Curitiba, v. 66, n. 2, p. 155-183, maio/ago. 2021. ISSN 2236-7284. Disponível em: https://revistas.ufpr.br/direito/article/view/74454. Acesso em: 31 ago. 2021. DOI: http://dx.doi.org/10.5380/rfdufpr.v66i2.74454.

\section{RESUMO}

Este artigo é resultado de pesquisa realizada para verificar se as alterações impostas pela Lei $\mathrm{n}^{\circ}$ 13.964/2019, em relação à utilização dos bancos de perfis genéticos para fins criminais, possibilitaram a superação dos antigos dilemas sobre essa temática, debatidos há alguns anos pelos estudiosos do direito no Brasil, e se enfrentaram os novos dilemas, discutidos em outros países, os quais questionam a sua adoção como ferramenta de combate ao crime. A partir de uma revisão bibliográfica teórico-narrativa, analisa-se a possível perpetuação das violações constitucionais decorrentes da utilização de bancos de perfis genéticos na nova legislação, examina-se de forma crítica a justificativa de eficácia desses bancos na solução de crimes, apresentada oficialmente para sua adoção pelo sistema de justiça criminal brasileiro, e exploram-se questionamentos que ainda podem surgir ante o uso da prova de DNA para fins de persecução criminal no Brasil. Além disso, reflete-se, de forma ensaística, como a utilização dos bancos de perfis genéticos pode incrementar a necropolítica reproduzida pelo sistema penal brasileiro. Conclui-se que a nova legislação radicalizou as violações constitucionais decorrentes da utilização do uso dos bancos de perfis genéticos para fins criminais, sem mesmo ter comprovado a sua eficácia, e não apresentou respostas para dilemas 
enfrentados por outros países que utilizam tal ferramenta probatória, assim continuando a alimentar a circularidade de pessoas negras e pobres nos cárceres, deixando-as ainda mais vulneráveis à morte.

\title{
PALAVRAS-CHAVE
}

Bancos de perfis genéticos. Identificação criminal. Lei nº 13.964/2019. Necropolítica brasileira.

\begin{abstract}
This article is the result of a research carried out to verify whether the changes imposed by Law $13,964 / 2019$, in relation to the use of DNA databases for criminal purposes, made possible the overcome of old dilemmas on this subject, which has been debated by Brazilians law scholars for some years, and whether it has faced the new dilemmas discussed in other countries, which put in question the adoption of such databases as a tool to fight crime. Based on a theoretical narrative literature review, it analyses the possible perpetuation of constitutional violations resulting from the use of genetic profile banks in accordance to the new legislation, critically examines the justification officially presented for its adoption by the Brazilian criminal justice system, regarding the effectiveness of these banks in solving crimes, and explores questions that may still arise in relation to the use of DNA evidence for criminal persecution purposes in Brazil. Moreover, it reflects, in an essayistic way, how the use of genetic profile banks can contribute to increase the necropolitics reproduced by the Brazilian criminal system. It is concluded that the new legislation radicalized the constitutional violations resulting from the use of genetic profile banks for criminal purposes, without even proving their effectiveness, and that it did not provide answers to dilemmas faced by other countries that use such evidence tool, thus continuing to feed the circularity of black and poor people in prisons, leaving them even more vulnerable to death.
\end{abstract}

\section{KEYWORDS}

DNA databases. Criminal identification. Brazilian Law 13,964/2019. Brazilian necropolitics.

\section{INTRODUÇÃO}

No Reino Unido ${ }^{1}$ e nos Estados Unidos (EUA) ${ }^{2}$, há mais de vinte anos é permitido o armazenamento de perfis genéticos em bancos de dados para identificação de autores e vítimas de crimes, mas não sem polêmicas em torno de dilemas éticos e jurídicos sobre o tema. Contudo, os questionamentos não têm sido suficientes para desacreditar esse meio de prova, pois outros países têm utilizado os bancos de perfis genéticos para resolver crimes, havendo atualmente 60 bancos de

1 O United Kingdom National DNA Database (NDNAD), criado em 1995 e considerado um dos mais antigos e maiores bancos de dados de DNA forense. Até o final de março de 2020, a base de dados continha 6.568.035 perfis cadastrados, correspondendo a 5.491.832 indivíduos (UNITED KINGDOM, 2020).

2 O Violent Crime Control and Law Enforcement Act of 1994 (42 U.S.C. 14132) autoriza a coleta de material biológico, sem consentimento, de pessoas indiciadas, detidas e condenadas por crimes federais, além de vestígios genéticos de locais de crimes e de humanos não identificados (UNITED STATES, 2008). Até fevereiro de 2020, o Combined DNA Index System-National DNA Index System (CODIS-NDIS), do Federal Bureau of Investigation (FBI), continha mais de 19 milhões de perfis cadastrados (UNITED STATES, 2020a, 2020b). 
dados para fins criminais espalhados pelo mundo, com a China, com cerca de 68 milhões de perfis genéticos armazenados, liderando o ranking ${ }^{3}$.

No Brasil, a criação desses bancos é recente, tendo sido prevista com a publicação da Lei ${ }^{\circ}$ 12.654/2012, que alterou as Leis $n^{0} 12.037 / 2009$ e $n^{0} 7.210 / 1984$, para tornar possível a identificação criminal por meio de perfil genético dos suspeitos da prática de crimes, quando imprescindível para as investigações e mediante ordem judicial, bem como dos condenados por crimes hediondos ou dolosos cometidos com violência grave contra a pessoa, os quais podem inclusive ser submetidos à extração compulsória de material genético. A Lei n ${ }^{0}$ 12.654/2012 determinou, ainda, que o acesso aos bancos de perfis genéticos para fins de persecução criminal somente poderá ocorrer mediante autorização judicial, uma vez que os dados são sigilosos. Por fim, advertiu que as informações contidas nos bancos não podem revelar traços somáticos ou comportamentais das pessoas, exceto a determinação genética de sexo, e devem ser excluídas no término do prazo para a prescrição.

A regulamentação sobre a instalação e funcionamento dos bancos ocorreu por meio do Decreto $n^{\circ}$ 7.950/2013, da Presidência da República, que instituiu o Banco Nacional de Perfis Genéticos (BNPG) e a Rede Integrada de Bancos de Perfis Genéticos (RIBPG) para permitir a comparação de perfis genéticos contidos nos bancos da União, dos estados e do Distrito Federal. Assim, os dados armazenados nos bancos de perfis genéticos brasileiros podem ser confrontados a nível interestadual e até internacional, “em busca de coincidências que permitam relacionar suspeitos a locais de crime ou diferentes locais de crime entre si” (BRASIL, 2019d, p. 10)4. O Decreto também estabeleceu que a RIBPG utilizará o sistema Combined DNA Index System (CODIS), criado na década de 1990 pelo FBI (UNITED STATES, 2020b) e que possibilita o cruzamento de dados de vários perfis genéticos em questão de minutos, com ínfima margem de erro, se comparado com outros sistemas (WALLACE, 2015, p. 90). Além disso, foi determinado que o banco de perfis genéticos também pode ser usado para identificação de pessoas desaparecidas, com a ressalva de que a amostra cedida pelos parentes das pessoas desaparecidas só poderá ser utilizada para esse fim, não podendo ser eventualmente utilizada para solucionar crimes.

Em que pese a implementação desses bancos ainda ser incipiente no País, a sua alimentação tem sido acelerada nos últimos anos. No início de 2019, haviam sido coletados sete mil perfis genéticos da população carcerária; já no final desse ano tinham sido colhidos 67 mil perfis, tendo sido

Cf. SIZE..., 2019.

4 Como o Brasil integra a Organização Internacional de Polícia Criminal (Interpol), desde janeiro de 2018 tem compartilhado perfis genéticos, vestígio de locais de crime, restos mortais e de pessoas desaparecidas, com outros países membros. Em novembro de 2019, ocorreu o primeiro match internacional. Cf. BRASIL, 2019d. 
cadastrados 55 mil no banco de dados, superando a meta do Ministério da Justiça e Segurança Pública (MINISTÉRIO..., 2019) de coletar 65 mil perfis até o final daquele ano. Recentemente, mais um importante capítulo foi acrescentado a essa história: a Lei $\mathrm{n}^{0}$ 13.964/2019, que promoveu significativas alterações em relação a essa matéria, prevendo que: (i) o condenado por crimes dolosos praticados com violência grave contra a pessoa, por crimes contra a vida, contra a liberdade sexual e por crimes sexuais contra vulneráveis ${ }^{5}$, que se negar a ceder o seu material genético, incorrerá em falta grave; (ii) deve-se garantir a proteção aos dados gerados a partir da colheita do material genético; (iii) a amostra biológica coletada só poderá ser usada para identificação do perfil genético e deverá ser imediatamente descartada, não estando autorizadas a fenotipagem genética ou busca familiar6; (iv) deve ser assegurado ao titular dos dados genéticos o acesso amplo aos dados contidos no banco e a todos os documentos que atestam a preservação da cadeia de custódia do material extraído; $(v)$ deve ocorrer exclusão imediata do perfil genético de pessoas absolvidas; (vi) o prazo para exclusão do perfil genético dos condenados passaria a ser de 20 anos após o cumprimento da pena, sem uma justificativa científica.

Diante desse novo panorama, a partir de uma revisão bibliográfica teórico-narrativa, a presente pesquisa busca analisar se as alterações promovidas pela Lei $n^{0}$ 13.964/2019 possibilitaram a solução dos antigos dilemas relativos ao uso dos bancos de perfis genéticos para fins criminais, debatidos há alguns anos pelos estudiosos do direito e pelos tribunais no Brasil, e se elas enfrentaram os novos dilemas, discutidos em outros países que adotam essa ferramenta no combate ao crime. Para tanto, investiga-se inicialmente se a nova legislação superou as violações de direitos e garantias constitucionais apontadas anteriormente à sua promulgação, de modo a justificar a introdução desse instrumento probatório no processo penal brasileiro. Num segundo momento, com base em pesquisas realizadas nos EUA e na Inglaterra, examina-se o grau de eficácia desses bancos de perfis genéticos na resolução de casos penais e os novos dilemas ético-jurídicos relativos ao manejo de tais dados genéticos, de modo a averiguar se o seu uso pode representar mesmo um avanço no combate ao crime no Brasil ou se pode gerar ainda mais violações. Por fim, diante da constatação dos problemas referentes aos bancos de perfis genéticos para fins criminais e com base na obra de Achille Mbembe (2017, 2018), realiza-se uma reflexão ensaística sobre como a ampliação desses bancos de eficácia

\footnotetext{
5 A redação original da Lei no 13.964/2019, promulgada em 24/12/2019, autorizava a extração compulsória do material genético de condenados por crimes hediondos. Contudo, após a derrubada dos vetos presidenciais pelo Congresso Nacional, em 30/04/2021, ficaram sujeitos à tal extração os condenados por crimes dolosos praticados com violência grave contra a pessoa, contra a vida, os crimes contra a liberdade sexual e crimes sexuais contra vulneráveis.

6 A vedação à utilização da amostra biológica para busca familiar e a previsão de seu descarte imediato após o registro do perfil no banco não estavam contidas na redação original da Lei $n^{\circ} 13.964 / 2019$. Tais disposições foram inseridas na lei após a derrubada dos vetos presidenciais pelo Congresso Nacional, em 30/04/2021.
} 
duvidosa se inserem no cenário da necropolítica desenvolvida pelo sistema penal brasileiro, como parte do dispositivo que mantém a circularidade de pessoas negras e pobres nas desumanas prisões, tornando ainda mais vulnerável à morte esse grupo que é marginalizado e criminalizado desde o período colonial.

\section{AS INCONSTITUCIONALIDADES CONTIDAS NA LEI No 13.694/2019 SOBRE A UTILIZAÇÃO DOS BANCOS DE PERFIS GENÉTICOS PARA FINS CRIMINAIS}

No Brasil, o debate sobre a constitucionalidade da utilização de bancos de perfis genéticos para resolução de crimes tem sido travado desde a edição da Lei $n^{0} 12.654 / 2012$, tendo chegado inclusive ao Supremo Tribunal Federal. Os questionamentos mais comuns dizem respeito ao fato de que a prova produzida a partir dos bancos de perfis genéticos pode violar o direito do acusado ao tratamento humano digno, o direito de não se autoincriminar, à presunção de inocência, à intimidade e ao esquecimento.

No que se refere à violação de alguns direitos da personalidade e do direito de não se autoincriminar, previstos no art. $1^{\circ}$ e no art. $5^{\circ}, \mathrm{X}, \mathrm{LVIII}$, da CF, o debate mais relevante gira em torno da constitucionalidade da extração compulsória do material genético dos condenados ${ }^{7}$. Essa discussão foi levada ao plenário do Supremo Tribunal Federal (2016), por meio do Recurso Extraordinário nº 973.837, que ganhou repercussão geral, em razão da decisão do seu relator, ministro Gilmar Mendes, o qual entendeu ser necessária a convocação de audiências públicas para ouvir especialistas sobre o tema e subsidiar a decisão da Corte.

Os principais argumentos levantados em tais audiências giraram em torno de que a extração compulsória do material genético de condenados viola primeiramente a dignidade da pessoa humana, na medida em que essa coleta e codificação do material genético dá acesso ao corpo do condenado, sem sua autorização (SCHIOCCHET, 2014, p. 92). Por mais que esse acesso seja limitado, tendo em vista que os marcadores genéticos armazenados nos bancos integram a parte não codificante do DNA, permitindo apenas determinar a identidade da pessoa, seu sexo biológico e suas possíveis relações de parentesco (SCHIOCCHET, 2015, p. 48-49), pode-se afirmar que essa prática permite um ingresso invasivo no corpo do condenado, desrespeitando sua integridade física (CHOUKR, 2004, p. 52) e

A extração compulsória do material genético de pessoas presas é autorizada em alguns países, tal como os EUA, que admitiu há alguns anos tal prática em seus estados (H.R.4614 - Katie Sepich Enhanced DNA Collection Act of 2010). Entretanto, não há um consenso dos estados sobre esse tema, e amplos debates têm sido travados sobre eventual violação da $4^{\text {a }}$ Emenda, que proíbe buscas infundadas. Cf. HENNING, 2010; UNITED STATES, 2010. 
revelando dados que dizem respeito à sua intimidade, tais como a realização de uma cirurgia de redesignação sexual e vínculos familiares, nem sempre conhecidos por ele.

A lei estabelece também que o método utilizado para a extração compulsória deve ser indolor, porém sabe-se que essa operação será realizada dentro do estabelecimento prisional, que não tem fiscalização adequada no Brasil (PAVARINI; GIAMBERARDINO, 2018). Em suma, ainda que a previsão legal estabeleça limites à invasão do corpo do condenado, a realidade das prisões brasileiras não permite garantir a sua integridade física no processo obrigatório de coleta de DNA.

Além disso, a extração compulsória de material genético viola o direito constitucional de não se autoincriminar, que impõe à acusação o ônus da prova do crime imputado, pois ao ter seu DNA extraído sem consentimento o condenado poderá estar produzindo provas que podem ser utilizadas contra ele num futuro processo criminal, considerando que as suas informações genéticas ficarão no banco de dados por um longo período após o cumprimento da pena, desonerando o Estado de sua carga probatória (QUEIJO, 2018, p. 242-243).

No mesmo sentido, pode-se pensar sobre a violação do princípio da presunção de inocência (MORAES, 2010), uma vez que a prova genética é fruto do conhecimento científico, hegemônico nas sociedades ocidentais, e por esse motivo se torna praticamente inquestionável no processo (FOUCAULT, 2001, p. 14). Então, caso o material genético coletado na cena de um crime encontre compatibilidade com o perfil de um indivíduo armazenado no banco, as investigações podem restar atrofiadas, pois rapidamente se deduzirá que, por ter sido condenado, ele é provavelmente o autor de mais esse delito, não havendo razão para perder tempo testando e investigando outras teses. Portanto, a presunção de inocência rapidamente se converteria em presunção de culpa.

Ainda quanto ao tema, é preciso ressaltar que o condenado, após o cumprimento da pena, tem o direito fundamental de ter seu delito esquecido, de reconstruir sua trajetória existencial, pessoal e social (SARLET, 2018, p. 497), livre do rótulo de criminoso; isto é, ele tem o direito de ter seu crime apagado de registros públicos por meio do chamado processo de reabilitação, sendo admissível a manutenção das informações das condenações anteriores apenas para fins de verificação de reincidência. Isso significa que a manutenção dos dados genéticos do condenado por tempo superior ao da reincidência é abusiva, viola a sua dignidade porque tem o único objetivo de estigmatizá-lo, prolongando o sofrimento imposto no tempo de privação da liberdade ao momento de reconstrução de sua trajetória, na medida em que lhe impõe desmedida segregação social (PAVARINI; GIAMBERARDINO, 2018). É certo que os dados contidos nos bancos são sigilosos e só podem ser acessados por pessoas autorizadas ou mediante ordem judicial, nos termos do art. $7^{\circ}-\mathrm{B}$, da Lei $n^{\circ}$ 12.037/2009, porém de acordo com o art. $6^{\circ}$ dessa lei, após o trânsito em julgado da condenação, o 
registro no banco poderá constar na ficha de antecedentes. Também não se pode ignorar a possibilidade de uma futura mudança legislativa que permita a divulgação seletiva dos dados contidos nos bancos, sob o pretexto de se defender a sociedade de certos inimigos (ZAFFARONI, 2007).

Não obstante todos esses argumentos, o Superior Tribunal de Justiça insiste em autorizar a coleta compulsória do material genético de condenados, sob o argumento de que a segurança da sociedade e o combate à impunidade devem estar acima dos direitos de um indivíduo condenado por crimes violentos (BRASIL, 2020). Tal posicionamento vem respaldado de alguma maneira pela Resolução no 9 do Comitê Gestor da Rede Integrada de Bancos de Perfis Genéticos, publicada em 26 de abril de 2018, que atribuiu ao Judiciário a responsabilidade por tomar as medidas cabíveis para que a coleta compulsória ocorra (BRASIL, 2018). Ademais, não se pode deixar de lembrar que a Resolução n ${ }^{\circ}$ 11/2019 editada pelo Comitê Gestor da RIBPG estabeleceu a possibilidade de retenção e inclusão do perfil genético de pessoas mortas; dessa forma, as informações genéticas do condenado morto continuarão armazenadas por 20 anos após a sua inserção nos arquivos de restos mortais identificados (BRASIL, 2019a).

Com relação às inconstitucionalidades até aqui apontadas, a Lei nº 13.964/2019 não inovou muito, pois manteve, na alteração proposta ao art. $9^{\circ}$ da Lei de Execução Penal (Lei nº 7.210/1984), a possibilidade de extração compulsória do DNA de condenados, não mais genericamente por crimes hediondos, mas agora especificamente por crimes dolosos praticados com violência grave contra a pessoa, contra a vida, por crimes contra a liberdade sexual ou crimes sexuais contra vulneráveis, devendo ser utilizada, à extração, técnica adequada e indolor. Contudo, a nova legislação paradoxalmente estabeleceu, no art. $9^{\circ}$-A, § $8^{\circ}$, da Lei de Execução Penal, que constituirá falta grave quando o condenado não se submeter à extração compulsória do material genético, colocando dúvidas sobre a alegada obrigatoriedade da coleta, na medida em que prevê a possibilidade de recusa do condenado a ceder seu DNA, embora sob ameaça de punição. Por certo, o temor do isolamento, dos obstáculos à progressão de regime e ao livramento condicional, quase não deixa escolha ao condenado e transforma em autossacrifício o direito de se recusar, considerando-se as condições dos cárceres brasileiros (ABRAMOVAY; BATISTA, 2010).

Isso significa que nada mudou e que as antigas violações constitucionais se encontram camufladas pela suposta dúvida quanto à obrigatoriedade da extração, provocada pela redação insidiosa da nova lei.

Outra alteração sobre essa matéria foi aquela introduzida, pela mesma Lei $\mathrm{n}^{0}$ 13.964/2019, no art. $9^{\circ}$-A, $\S 4^{\circ}$, da Lei de Execução Penal, ao prever que se não for realizada a identificação do perfil genético do indivíduo por ocasião do ingresso no estabelecimento prisional, ele deverá ser 
submetido ao procedimento durante o cumprimento da pena. Essa disposição sem dúvida é oblíqua e permite algumas interpretações mais próximas ou mais distantes da Constituição, ao sabor dos ventos autoritários. Por um lado, pode-se entender que o suspeito ou acusado por crime doloso praticado com grave violência contra a pessoa, contra a vida e crimes sexuais, ao ser preso cautelarmente e submetido à identificação criminal por ordem judicial, não precisará realizar novamente a extração do material genético quando condenado definitivamente. Por outro lado, pode se seguir a recomendação contida na justificativa do Projeto de Lei (PL) nº 882/2019 (BRASIL, 2019b), que deu origem a Lei $\mathrm{n}^{\circ}$ 13.964/2019, a qual estabelece ser possível coletar compulsoriamente o DNA de todos os condenados pelos referidos crimes, ainda que não se tenha o trânsito em julgado, até porque não é desarrazoado apostar que mais cedo ou mais tarde o Supremo Tribunal Federal poderá mudar sua posição sobre a possibilidade de execução provisória da sentença condenatória, como tem feito nos últimos tempos em relação a essa questão ${ }^{8}$. Inclusive, esse raciocínio seria compatível com a nova redação do art. 492 do Código de Processo Penal (Decreto-Lei ${ }^{\circ}$ 3.689/1941), dada pela Lei $n^{\circ}$ 13.964/2019, que permitiu a execução provisória das penas iguais ou superiores a 15 anos fixadas pelo Tribunal do Júri. Nesse caso, o direito constitucional à presunção de inocência seria mais uma vez violado.

Por fim, não se pode deixar de mencionar que a Lei n ${ }^{0} 13.964 / 2019$, ao inserir o art. $7^{\circ}$-A na Lei $n^{\circ} 12.034 / 2009$, agravou ainda mais a violação do direito ao esquecimento, quando aumentou o tempo de armazenamento das informações genéticas dos condenados para 20 anos após o cumprimento da pena. Se antes esse prazo se limitava ao prazo prescricional do delito, atualmente ele alcança praticamente boa parte da vida do condenado, abrangendo principalmente o tempo que ele teria para se reinserir no mercado de trabalho, algo quase impossível, em razão da estigmatização social sofrida, para alguém condenado por crime violento ou sexual, mas que agora se encontra ainda mais distante, confirmando a função de neutralização do sistema penal (ZAFFARONI et al., 2006).

Em outras palavras, dadas as condições do sistema penitenciário brasileiro, a possibilidade ínfima que o condenado teria de ver seu crime esquecido, de reinventar sua existência após o cumprimento da pena, de trabalhar, de restabelecer laços sociais, de se afastar do crime e do sistema penal, foi praticamente anulada com a nova lei, tornando sua reincidência ainda mais certa e confirmando a função secundária, de criminalização, do cárcere (BARATTA, 2002).

Além do mais, é preciso ter claro que a reflexão sobre o tempo de manutenção dos perfis genéticos no banco deve ter em vista a realidade de cada país, pois em alguns países que admitem a

8 Sobre posições contrárias no STF, cf. BRASIL, 2010, 2019c. Sobre posições a favor na mesma corte, cf. BRASIL, 2017a. 
prisão perpétua, esse prazo é obviamente maior. Portanto, não se autorizam conclusões rasteiras no sentido de que o prazo de manutenção dos registros genéticos nos bancos brasileiros é curto se comparado a outros países; faz-se necessário pensar nesse prazo considerando-se a legislação brasileira $^{9}$. Aliás, foi nesse sentido a Recomendação $n^{0} 92$ do Comitê de Ministros do Conselho Europeu, de 10 de fevereiro de 1992, ao estabelecer que cabe à legislação interna dos países da União Europeia fixarem o tempo de retenção das amostras e registros de DNA.

Enfim, como se pode perceber, a Lei $\mathrm{n}^{0}$ 13.964/2019 manteve ou agravou as inconstitucionalidades da legislação anterior sobre a utilização dos bancos de perfis genéticos para fins criminais. Diante disso, resta saber se o preço dessas violações de direitos é vantajoso e se os bancos de perfis genéticos contribuem efetivamente para a resolução de crimes e servem aos propósitos aventados na justificativa apresentada para aprovação do PL nº 882/2019, isto é, para tornar as investigações técnicas e científicas, evitando erros, identificando criminosos rapidamente e impedindo condenações indevidas.

Ademais, igualmente é necessário indagar se o Brasil está preparado para enfrentar os novos dilemas que envolvem esse tema, tais como a possibilidade de identificar criminosos por meio da busca de compatibilidade do material genético deixado na cena do crime com o DNA de seus parentes registrados em bancos de dados públicos e privados.

\section{A EFICÁCIA DOS BANCOS DE PERFIS GENÉTICOS NA RESOLUÇÃO DE CRIMES: ALGUNS QUESTIONAMENTOS A PARTIR DAS EXPERIÊNCIAS ESTADUNIDENSE E EUROPEIA}

Para avaliar a eficácia dos bancos de dados de DNA forense, pode-se consultar alguns estudos realizados no Reino Unido e nos Estados Unidos, os quais fornecem indicadores quanto à contribuição desses bancos para a segurança pública em detrimento das metodologias tradicionais de investigação. A literatura revela sete indicadores pelos quais são possíveis avaliar a eficácia: o efeito dissuasivo, o efeito incapacitante, a resolução de casos, a otimização de tempo, o esforço, o custo e a proteção de direitos individuais (AMANKWAA; MCCARTNEY, 2019, p. 47).

Para testar o efeito da coleta de DNA nos comportamentos de infratores, Jennifer L. Doleac (2017, p. 165-168), da Universidade da Virgínia, comparou em sete estados os indivíduos libertos da

9 A única regra que tem respaldo na maioria dos países é a que determina a exclusão imediata dos registros genéticos daqueles que foram absolvidos, nos termos da nova redação do art. $7^{\circ}$-A da Lei $\mathrm{n}^{\circ}$ 12.037/2009, e da interpretação do art. $8^{\circ}$ da Convenção Europeia dos Direitos Humanos, realizada pelo Tribunal Europeu dos Direitos Humanos ao julgar o caso S. and Marper v. the United Kingdom, em 04/12/2008 (EUROPEAN COURT OF HUMAN RIGHTS, 2008). 
prisão antes da expansão dos bancos de dados ( $1^{\circ}$ grupo) e nos cinco anos seguintes a ela ( $2^{\circ}$ grupo), ou seja, ambos os grupos sujeitos às mesmas políticas e práticas de justiça criminal, porém os indivíduos do segundo grupo cadastrados no banco de dados de DNA e, portanto, com maior probabilidade de serem pegos em caso de reincidência. Constatou-se, então, uma redução da probabilidade de reincidência de, pelo menos, $17 \%$ quanto aos infratores por crimes violentos e de 6\% quanto aos infratores por crimes contra a propriedade, ao contrário, por exemplo, dos registros de agressores sexuais, em que se verificou um aumento dessa probabilidade.

Diferentemente concluiu Avinash Bhati (2010, p. 99), da Temple University, da Filadélfia, que realizou um estudo com base em dados observacionais, com o intuito de quantificar os efeitos dissuasores específicos das bases de dados de DNA. Para tanto, analisou os padrões de reincidência de um grupo de infratores libertos da custódia do Departamento de Correções da Flórida, entre 1996 e 2004.

Os resultados demonstraram que pequenos efeitos dissuasores, com redução de $2 \%$ a $3 \%$ do risco de reincidência, foram atribuídos apenas para as categorias de crimes como roubo e furto, indicando que uma medida de expansão nas bases de dados de DNA deve ser focada em crimes contra a propriedade. De outro lado, para a maioria das categorias de ofensas houve um aumento de 20\% a 30\% no índice de reincidência, demonstrando que os bancos de perfis genéticos não produziram um grande impacto na redução de crimes.

Em termos de resultado, um estudo realizado por Paul E. Tracy e Vincent Morgan (2000, p. 685-690) apontou que as evidências de DNA apenas contribuem para solucionar os crimes considerados violentos e sexuais, em que ocorre o contato vítima-agressor. Consequentemente, os autores indicaram haver menos eficácia para resolução de crimes contra a propriedade, que representavam maior número no índice de criminalidade do FBI. Isso porque, naquela época, era improvável que a cena usual do crime de ofensa à propriedade tivesse o DNA dos autores e, mesmo que isso acontecesse, essas evidências raramente seriam apreendidas, coletadas e testadas.

Corroborando esse estudo, na Inglaterra e no País de Gales, Jon Burrows e Roger Tarling (2004) investigaram a contribuição das evidências forenses, incluindo o DNA, na resolução de crimes patrimoniais, utilizando os dados constantes no Pathfinder Project do Ministério do Interior, entre junho de 2000 e maio de 2001. Os autores concluíram que, no geral, 4\% das cenas visitadas levaram à detecção de crimes usando correspondências de DNA e estimaram que $10 \%$ dos crimes contra a propriedade são detectados pela polícia. As impressões digitais e o DNA contribuíram com 33,3\% dessas detecções. O estudo mostrou que, embora as evidências de DNA pareçam desempenhar um 
papel crucial no crime de propriedade, sua contribuição geral para a resolução do crime permanece muito baixa.

A perspectiva investigativa quanto ao uso do DNA em crimes contra o patrimônio passou a mudar em meados dos anos 2000. Três projetos-pilotos do National Institute of Justice demonstraram, em 2006, por intermédio de algumas evidências indiretas, que analisar DNA nas cenas de crimes contra a propriedade poderia ser extraordinariamente útil. No geral, em Nova York, por exemplo, as evidências biológicas de 201 assaltos renderam 86 perfis “aceitáveis no CODIS” e 31 correspondências (15,4\%). No condado de Miami-Dade, 526 perfis aceitáveis no CODIS e retirados de casos não resolvidos produziram 271 ocorrências. Já em Palm Beach, 229 perfis produziram 91 hits. Das 362 amostras correspondentes ao CODIS, mais da metade (56\%) veio de evidências coletadas em cenas de roubo. Esses estudos foram utilizados para expandir a análise de DNA, embora os resultados apresentados não significassem a resolução efetiva dos casos, isto é, processos e condenações (ZEDLEWSKI; MURPHY, 2006).

Para avaliar a expansão da coleta e testes de evidências de DNA para resolver crimes de propriedade, incluindo roubo residencial, comercial e de automóveis, John Roman et al. (2009) realizaram um estudo randomizado da relação custo-efetividade, com até 500 cenas de crimes em cinco cidades dos EUA entre 2005 e 2007. Os resultados apontaram que o uso de DNA dobrou o número de vezes na qual os suspeitos foram identificados, presos e processados, em comparação à investigação tradicional, que usava impressões digitais. Além disso, o DNA teria oferecido pelo menos cinco vezes mais chances de resultar em uma identificação suspeita, demonstrando ser mais eficaz. De outro lado, é preciso ressaltar que não ficou claro no estudo o motivo pelo qual o processamento de DNA foi superior às impressões digitais na identificação de suspeitos (até então inesperado), ou ainda quantos casos de roubos potencialmente produziram uma amostra biológica, uma vez que, nesses casos, os perfis de DNA são raramente encontrados.

A título de curiosidade, consta no relatório da RIBPG referente ao período de maio a novembro de 2019 (BRASIL, 2019d) que 62\% das coincidências envolvendo vestígios estão relacionadas a crimes sexuais e 34\% a crimes contra o patrimônio. Já as coincidências entre vestígios e indivíduos cadastrados criminalmente são mais comuns em crimes contra o patrimônio (54\%) do que em crimes sexuais (42\%). O maior impacto dos bancos de dados em crimes patrimoniais pode ser explicado pelo fato de a identidade do suspeito ser frequentemente desconhecida. Desde então, tem-se que a eficácia do DNA na solução de crimes investigados tradicionalmente por métodos alternativos (crimes patrimoniais) pode ter mais impacto do que na resolução de crimes sexuais. 
A baixa contribuição do CODIS nos crimes sexuais ao longo dos últimos anos foi demonstrada pelo projeto de Theodore P. Cross Jr. et al. (2020), que analisaram casos de abuso sexual envolvendo 528 adultos e adolescentes e 36 crianças, de Massachusetts, entre 2008 e 2010. Os autores buscaram estabelecer a relação entre evidência biológica e prisão. Para tanto, utilizaram três fontes: (i) bases de dados de exames médicos forenses; (ii) relatório dos dois laboratórios criminais do Estado; e (iii) dados de 142 departamentos policiais. Os resultados revelaram que o DNA poderia ter influenciado apenas 11 casos em que o relatório do laboratório criminal foi finalizado antes da prisão; portanto, permitiram concluir que os meios alternativos utilizados pela polícia podem ser mais eficazes do que a análise do perfil de DNA no banco de dados. A baixa eficácia do banco de dados em crimes violentos pode ser explicada pelo fato de os autores, na maioria das vezes, serem conhecidos por suas vítimas. Nesses casos, o banco de dados é irrelevante para a identificação do suspeito, salvo nos casos de serial killers.

Em termos de contribuição geral, resultados opostos já foram fornecidos. Jennifer L. Doleac (2017, p. 167) indicou que cada perfil adicional de DNA (por 100.000 habitantes) resultou, em média, na redução de 7\% a 45\% das taxas anuais de crimes violentos, entre 2000 e 2010. Nos crimes de propriedade, essa média de redução girou em torno de 5\% a 35\% no mesmo período. De acordo com esse estudo, o uso de DNA forense, além de aumentar a probabilidade de reincidentes serem pegos por seus crimes, inibe a reincidência ante o reconhecimento, pelos eventuais infratores, do potencial dessa ferramenta.

Ao contrário, o recente estudo realizado por Aaron Amankwaa e Carole McCartney (2019), com a finalidade de medir a eficácia do National DNA Database (NDNAD) do Reino Unido, revelou que, embora a taxa de correspondência ${ }^{10}$ possa ser alta, tendo atingido seu nível mais alto de 2013/2014 para 2017/2018 (de 62\% para 66\%), a proporção de crimes examinados em busca de provas forenses caiu de 12,8\% em 2014/2015 para 11\% em 2015/2016, revelando que a contribuição geral do banco de dados permanece baixa (AMANKWAA; MCCARTNEY, 2019, p. 49) ${ }^{11}$.

Quanto ao impacto na resolução de crimes no geral, o DNA estava "ligado ao resultado" em apenas 0,3\% de todos os crimes registrados na Inglaterra e no País de Gales em 2015/2016, segundo o Comissário de Biometria. Essa baixa taxa permanece inalterada desde que o banco de dados foi

10 “A taxa de correspondência é calculada dividindo o número de correspondências entre os perfis de cena de crime carregados e os perfis de sujeitos retidos pelo número total de perfis de cena de crime carregados” (AMANKWAA; MCCARTNEY, 2019, p. 49, tradução nossa).

11 Deve-se lembrar que, para se aferir a contribuição dos bancos de DNA, no Reino Unido é relatada a taxa na qual o DNA foi ‘vinculado ao resultado’, ao contrário do Brasil e dos Estados Unidos, que medem conforme a contribuição para a investigação criminal. 
criado em 1995. A título de comparação, o impacto é de $0,6 \%$ nos crimes de estupro, 1,4\% nos roubos domésticos e 8,4\% nos casos de homicídio. O resultado é que, mesmo nos casos em que se espera que o DNA seja importante, ele ainda é, na maioria das vezes, insignificante como ferramenta de solução de crimes.

Apesar do forte apoio do governo e do alto investimento financeiro no DNA Expansion Programme 2000-2005 (destinado a melhorar a eficácia do NDNAD), as evidências de DNA permaneceram marginais nos anos seguintes em termos de assistência às detecções criminais gerais. Durante 2006/2007, apenas 0,40\% (19.949) de aproximadamente cinco milhões de crimes registrados no período foram detectados utilizando DNA, caindo para 0,35\% (17.614) em 2007/2008 (AMANKWAA; MCCARTNEY, 2019, p. 46), sugerindo que a expansão maciça do banco de dados nacional de DNA não resultou na melhoria inicialmente prevista das taxas de detecção (MCCARTNEY, 2006).

Os custos de processamento e investigação de um caso com evidência de DNA dependem de vários fatores, tais como: salários de cientistas forenses, policiais e detetives, intensidade e otimização do trabalho no processamento de casos, custo dos suprimentos, número de amostras analisadas em um caso médio, terceirização ou não do processamento dos dados, etc. John Roman et al. (2009, p. 359-362) demonstraram que a análise de DNA é muito mais cara que o uso de impressões digitais. Por exemplo, o custo por suspeito identificado (que, de outra forma, não teria sido) foi de aproximadamente US\$ 4.500, desde o momento em que a evidência foi entregue ao laboratório forense e até a identificação do suspeito. Somados o custo médio adicional por prisão e por caso aceito para acusação, o valor salta para US\$24.840. A análise do custo-efetividade escolhido pelos autores, não determina, por outro lado, se empiricamente os custos por resultado valem a pena para o uso ampliado de DNA nas investigações.

Tentando trazer à discussão essa relação de custo-benefício, Jennifer L. Doleac (2017, p. 198-200) sustenta que os altos custos iniciais, com laboratórios criminais e equipamentos, ao longo do tempo se tornam relativamente pequenos. Em seus cálculos, se atualmente o custo de coleta e análise de cada amostra de DNA é inferior a US\$ 40 (estimativa do Departamento de Justiça dos EUA), e se cada adição de perfil de DNA resulta em menos 0,07 a 0,68 crime grave, multiplicados pelo custo social estimado de cada crime, chega-se a uma economia entre US\$ 1.566 e US\$ 19.945 por perfil. No final das contas, a pesquisa concluiu que, em termos de redução de crimes, os bancos de DNA são muito mais econômicos que os métodos tradicionais, como o aumento de pena e contratação de policiais. Isso porque: (i) aumenta-se a probabilidade de infratores serem presos, 
impedindo-se novos crimes; (ii) o processamento dos dados é praticamente imediato; e (iii) aumentase a precisão de condenações e prisões, evitando-se os custos implicados na condenação de inocentes.

Em todos os resultados apresentados, denota-se a existência de dificuldades em isolar os efeitos de um banco de DNA, como a falta de clareza sobre como as correspondências contribuem para a resolução do crime e o resultado dos casos. Essa dificuldade está atrelada às variáveis envolvidas em todos os indicadores ${ }^{12}$. De todo modo, até hoje não foi possível comprovar efetivamente a eficácia (valor agregado) dos bancos de perfis genéticos, isso porque os modelos desenvolvidos para essa avaliação, na pequena proporção de crimes em que são úteis, apenas fornecem estimativas que podem não refletir a eficácia real. Aliás, a maioria das estimativas indicam baixo retorno em termos de cientificidade nas investigações, seja para identificação rápida de criminosos, seja para a exclusão de suspeitos inocentes.

Ademais, se a eficácia dos bancos de perfis genéticos também deve ser medida em termos de proteção de direitos individuais, em especial a privacidade genética, bem como em termos de sua proporcionalidade aos interesses de segurança pública, não é possível afirmar, ao menos por ora, que os poucos benefícios advindos da identificação criminal pelo DNA, com retornos cada vez mais decrescentes, tenham o condão de superar as inconstitucionalidades evidenciadas no procedimento de coleta e armazenamento dos perfis, inclusive agravadas com a Lei n ${ }^{\circ}$ 13.964/2019.

Essa baixa contribuição dos bancos genéticos forenses, nos moldes em que originalmente foram concebidos, levou os administradores dos bancos e investigadores de outros países a buscarem alternativas com a utilização do material genético na procura de suspeitos, a fim de potencializar a eficácia da persecução penal em uma escala muito mais ampla. Contudo, paralelamente, tornou-se inevitável a ampliação das violações a direitos fundamentais.

\section{O USO DE INFORMAÇÕES GENÉTICAS FAMILIARES PARA RESOLUÇÃO DE CRIMES}

Ao longo dos últimos anos, a privacidade genética encontrou um novo dilema: o mapeamento genético de parentes de criminosos. A “busca familiar”, em princípio, não autorizada no Brasil, é uma forma de estabelecer relações familiares entre o perfil genético encontrado na cena do crime e qualquer membro da família (parentes em potencial) do autor do fato, que possa estar nos bancos de dados genéticos, podendo levar à sua identificação, até então desconhecida (GARCÍA;

\footnotetext{
12 Por exemplo, quanto à resolução de crimes, defende-se que a interpretação deve ser ampla, abrangendo: eliminação de suspeitos; ligação entre os crimes; redução do tempo de investigação e resolução do caso. Cf. AMANKWAA; MCCARTNEY, 2019, p. 47.
} 
CRESPILLO; YURREBASO, 2017, p. 27). Ressalte-se que essa pesquisa pode ser aplicada tanto nos bancos genéticos forenses, quanto nas plataformas privadas de genealogia genética.

Essa estratégia é baseada na semelhança genética existente entre parentes (vínculo genético), que aumenta de acordo com o grau de parentesco entre eles, e se utiliza da mesma metodologia aplicada para busca de pessoas desaparecidas, por meio da identificação indireta, sendo necessária a construção de árvores genealógicas, com um ou mais familiares (BRASIL, 2017b). O objetivo é encontrar uma correspondência parcial ${ }^{13}$ entre os perfis genéticos oriundos das cenas de crime e os perfis de indivíduos inseridos no banco (GARCÍA; CRESPILLO; YURREBASO, 2017, p. 27), que podem ser pais, filhos ou irmãos do suspeito. Permite-se, assim, uma nova linha de investigação, quando outras não forem suficientes.

As comparações podem ser realizadas com marcadores de cromossomos Y e/ou mitocondriais (mtDNA), que ajudam a estabelecer uma relação de parentesco paterno e/ou materno, respectivamente. Outra forma é buscar correspondências em um grande número de alelos que os perfis genéticos existentes no banco compartilhem, a fim de estabelecer uma classificação de similaridade (short tandem repeat - STR), podendo ser direcionada aos alelos raros. Por fim, outras estratégias de busca são voltadas para o uso de algoritmos matemáticos que calculam relações de parentesco (razão de verossimilhança ou LR, na sigla em inglês), o que também pode ser combinado com a busca a alelos raros (GARCÍA; CRESPILLO; YURREBASO, 2017, p. 27).

A data mining ajuda a refinar a lista e eliminar pistas falsas, sendo utilizada em conjunto com técnicas tradicionais de investigação, como informações públicas disponíveis, vigilância no geral, interrogatório de familiares, solicitação de amostras voluntárias ou coleta clandestina de DNA em locais públicos, componentes estes responsáveis pela eficácia da técnica. Estima-se que, se hipoteticamente a taxa de cold hits - a chance de encontrar uma correspondência entre uma amostra da cena do crime e alguém no banco de dados de infratores - for de 10\%, a análise do parentesco poderia aumentá-la para 14\% (BIEBER; BRENNER; LAZER, 2006, p. 1.315-1.316). Assim como a eficácia da identificação direta depende da existência de registro do perfil do autor do fato nos bancos genéticos, o sucesso da busca familiar também depende de um parente próximo do perpetrador ter sido cadastrado nesses bancos genéticos.

\footnotetext{
13 "Uma correspondência parcial é o produto espontâneo de uma pesquisa regular no banco de dados em que um perfil de candidato a agressor é identificado como não sendo idêntico ao perfil forense, mas, considerando-se uma semelhança no número de alelos compartilhados entre os dois perfis, o agressor pode ser um parente biológico da fonte do perfil forense” (UNITED STATES, 2020b, tradução nossa).
} 
Quanto aos bancos genéticos forenses, entusiastas baseiam-se em estudos que apontam, do ponto de vista criminológico, a alta probabilidade de um membro da família vir a ser preso se algum parente próximo também já tiver sido preso, em virtude de conviverem no mesmo ambiente social e econômico (FARRINGTON et al., 2001). Na mesma linha, o Departamento de Justiça dos Estados Unidos (UNITED STATES, 1999, p. 62) apontou que 46,1\% da população carcerária do país afirmou ter tido pelo menos um parente próximo preso. Essa perspectiva reforça estudos indicando que parentes economicamente desfavorecidos tendem a viver em áreas geográficas próximas, além do fato de criminosos geralmente cometerem seus atos próximos aos locais onde vivem (BERNASCO; KOOISTRA, 2010; ROWE; FARRINGTON, 1997).

Além disso, afirma-se também que esse tipo de investigação exige muito tempo e esforço que poderiam ser despendidos em métodos tradicionais de investigação, já que não levará ao exato autor do crime. Informações familiares ocultas e privadas podem ser reveladas (adoção, incesto, passagem criminal, etc.), mediante as quais a privacidade restará completamente violada. Ainda, considerando que certos grupos (por exemplo, étnicos e classes sociais) possuem maiores taxas de encarceramento, estes serão super-representados nos bancos genéticos criminais, levando à sua maior submissão a investigações, em relação a outros grupos (ROHLFS et al., 2014). Por fim, o procedimento não é isento de falhas, em razão da alta taxa de falsos positivos, o que pode gerar erros e atrasos na investigação policial (GARCÍA; CRESPILLO; YURREBASO, 2017, p. 30).

Mas, apesar de praticamente inexistir legislação a respeito, esse novo mecanismo de investigação criminal está sendo implementado em vários países. Diferentes políticas de governança estabelecem diferentes limitações, salvaguardas e mecanismos de supervisão. O Reino Unido foi o primeiro a implementar a técnica em 2002, adotando protocolos detalhados que incluem um processo de aprovação, considerações para priorização, pesquisa de história da família e treinamento de policiais. A técnica tem sido utilizada em casos graves ou em cold hits, com a correspondência sendo feita em pelo menos 11 dos 20 alelos analisados e com os suspeitos sendo posteriormente classificados com base em seus índices de parentesco e outras informações, tais como idade, cromossomo Y, local de residência, etc. O serviço foi inicialmente fornecido pela Forensic Science Service (FSS), que entre 2002 e 2011 colaborou com pesquisas familiares em 188 investigações policiais, levando à identificação de 41 perpetradores ou suspeitos (MAGUIRE et al., 2014, p. 1), e atualmente é realizado pelo setor privado. 
Nos EUA, a busca familiar ${ }^{14}$ não é conduzida pelo Sistema Nacional de Índice de DNA (National DNA Index System, ou NDIS), por não ter sido recomendada pelo Grupo de Trabalho Científico sobre Métodos de Análise de DNA (UNITED STATES, 2009). Porém, em 2009, o FBI implementou um plano provisório para permitir aos estados buscar correspondências parciais identificadas no NDIS, de acordo com as regras e regulamentos de cada jurisdição local.

Não obstante, em 2010, o parlamentar Adam Schiff propôs na Câmara dos Representantes o Projeto de Lei Federal HR 6011, para autorizar o FBI a realizar buscas familiares no âmbito nacional, quando nenhuma correspondência idêntica for encontrada e para os casos de crimes violentos, sexuais ou contra menores de idade (UTILIZING..., 2010). Enquanto não aprovado o projeto, cada estado possui um regulamento ou protocolo administrativo que disciplina a possibilidade de busca familiar e o uso de correspondências parciais. Atualmente, Arkansas, Califórnia, Colorado, Flórida, Michigan, Texas, Utah, Virgínia, Wisconsin e Wyoming adotam o método Combined DNA Index System (UNITED STATES, 2020b), enquanto Maryland e Washington, D.C. proíbem expressamente a busca familiar (CODE..., 2016; 2010 MARYLAND..., 2010).

A técnica se torna ainda mais controversa quando agências policiais começam a utilizar bancos de dados de genealogia genética de empresas privadas (recursos para a descoberta de ancestralidade, características físicas e avaliação de riscos à saúde, utilizando testes genéticos) para a busca familiar ${ }^{15}$. O objetivo consiste em encontrar autores de crimes, principalmente em cold cases $^{16}$, por meio de parentes cadastrados voluntariamente nessas plataformas. Esse método teve seu momento decisivo em abril de 2018, no caso Golden State Killer da Califórnia ${ }^{17}$, embora não tenha sido o primeiro.

A plataforma GEDmatch, com serviço gratuito hospedado em site e essencialmente executado por usuários voluntários, foi a principal fonte de pesquisa em genealogia genética utilizada pelas agências policiais dos EUA entre 2018 e 2019, inclusive no caso Golden State Killer. Por ser

14 Um dos casos mais emblemáticos nos EUA é o do serial killer Lonnie David Franklin Jr., mais conhecido como Grim Sleeper. Acredita-se que ele tenha sido responsável por, no mínimo, 10 homicídios ocorridos em Los Angeles, na década de 1980. Em 2010, uma pesquisa no banco de dados pelo perfil genético encontrado nas cenas desses crimes permitiu a identificação do filho dele e posteriormente a dele, levando-o à prisão. Cf. NARAYAN, 2016.

15 Essas empresas possuem um teste de marcador de determinada área do perfil, que permite as correspondências parciais de DNA e a descoberta de pessoas que compartilham do mesmo DNA da amostra oriunda de uma cena de crime.

16 Crimes, ou suspeitas de crimes, ainda não totalmente resolvidos e que não são objeto de investigação criminal recente, mas para os quais podem surgir novas informações a partir de depoimentos de novas testemunhas, reexame de arquivos, evidências materiais novas ou retidas, bem como novas atividades do suspeito. Cf. DAVIS, 2021.

17 Joseph James DeAngelo praticou homicídios, estupros e agressões nas décadas de 1970 e 1980, em vários condados da Califórnia. Até 2018, ele não havia sido identificado como autor dos crimes, mas após as autoridades utilizarem o banco de dados de genealogia de DNA GEDmatch para rastreá-lo, ele está preso e responde a 26 acusações. Cf. ROBBINS, 2018. 
até então um site cujos dados dos usuários eram livremente compartilhados (open-source intelligence), nenhuma ordem judicial ou intervenção dos administradores foi necessária para acesso a esses dados, que também auxiliaram em outras 70 investigações criminais naquele período. Nos atuais termos de sua política de privacidade, a GEDmatch adverte que dados brutos, informações pessoais e dados genealógicos só podem ser divulgados para fins de cumprimento de ordem judicial (GEDMATCH.COM..., 2019).

Outros sites com fins comerciais também são utilizados para fins forenses. Os mais conhecidos são os das empresas 23andMe, Ancestry, FamilyTreeDna e o MyHeritage. Nos termos de privacidade da 23andMe, as informações genéticas podem ser compartilhadas ou divulgadas se exigido por lei ou por ordem judicial (PRIVACY..., 2020). Até 2019, nenhuma solicitação foi cumprida por falta de requisito. A Ancestry permite o compartilhamento de informações genéticas mediante ordem judicial, oriunda de um processo válido. Em seu relatório de transparência de 2019 (2019 TRANSPARENCY..., 2019), oito das nove solicitações cumpridas estavam relacionados a investigações envolvendo uso indevido de cartão de crédito, fraude e roubo de identidade. Quanto aos termos da FamilyTreeDNA (2019), as informações genéticas podem ser compartilhadas com a autoridade judicial ou policial ou outra entidade governamental. Além disso, mediante a concordância do consumidor, pode ser criada uma conta específica para fins de aplicação da lei, situação em que os usuários ou os parentes destes ficarão visíveis na conta. No MyHeritage, a informação pessoal pode ser divulgada se exigido por lei ou para a proteção de direitos da empresa ou a propriedade de outros usuários, sendo a primeira empresa da área com atuação no Brasil (POLÍTICA..., 2020).

Essa maneira incomum do uso, pela polícia, de um banco de dados de ancestralidade para solucionar casos criminais levanta preocupações sobre como as informações genéticas, enviadas voluntariamente pelos consumidores, estão sendo utilizadas para atividades de investigação e repressão de infrações penais, inclusive quando prescindem de consentimento, o que revela um excesso de Estado orwelliano. Além de a privacidade restar comprometida, as informações podem ser utilizadas indevidamente para diversos fins, incluindo: vigilância governamental (por exemplo, identificar origens étnicas para fins imigratórios), atividade criminosa (por exemplo, roubo de identidade), exploração e rastreamento para fins comerciais (por exemplo, venda de dados genéticos supostamente anônimos para terceiros) e discriminação genética (por exemplo, predisposições à criminalidade) (THE DNA..., 2006).

Nesse sentido, a busca familiar em bancos genéticos representa uma mudança crítica no uso de bancos de dados para fins forenses pelo governo, à medida que a técnica se torna mais prevalente. Isso porque o método permite a identificação não apenas de potenciais suspeitos, mas também de 
seus parentes, além do escrutínio de suas vidas particulares, sem o qual a pesquisa genética familiar é ineficaz. A biovigilância passa então a atingir, além do suspeito, o seu meio familiar.

\section{OS BANCOS DE PERFIS GENÉTICOS NO CENÁRIO DA NECROPOLÍTICA DO SISTEMA PENAL BRASILEIRO}

Como se viu, diversos questionamentos foram feitos desde o início da implantação dos bancos de perfis genéticos no Brasil e muitos outros estão por vir, o que demonstra uma incerteza em relação aos resultados que podem ser alcançados com essa medida de combate ao crime, tanto no que se refere à solução dos delitos propriamente ditos, quanto no que diz respeito à efetivação de direitos e garantias constitucionais. Então, resta a indagação sobre o que realmente justificaria esse investimento tão oneroso e duvidoso para o Estado brasileiro, que tem dificuldade para tratar de problemas sociais básicos de sua população, tais como a fome, a falta de postos de trabalho, o analfabetismo funcional, a falta de saneamento básico. Para formular uma resposta a essa questão é preciso identificar os propósitos a serem alcançados com a implementação dos bancos de perfis genéticos para fins criminais no contexto brasileiro; ou melhor, significa, numa perspectiva necropolítica, compreender como o dispositivo da segurança concretizado na implementação dos bancos de perfis genéticos contribuirá para fazer morrer grupos considerados perigosos para a população escolhida, pelo mercado, para viver.

Achille Mbembe, filósofo camaronês, em sua obra Necropolítica (2018), busca realizar uma leitura descolonizadora da biopolítica foucaultiana, considerando as especificidades do governamento neoliberal das populações nos países periféricos. Para tanto, demonstra que o racismo, tal como retratado pelo filósofo francês no Em Defesa da Sociedade (FOUCAULT, 1999), permeia inexoravelmente as práticas de poder nos países periféricos, fazendo com que a biopolítica se torne uma necropolítica do mercado, ou que as ações do poder público e dos indivíduos, pautadas pela grade da inteligibilidade econômica (FOUCAULT, 2008, p. 338), transformem-se em máquinas de guerra, que farão morrer ou transformarão em mortos-vivos certos grupos que se colocam como obstáculo à manutenção daquela parcela da população que deve viver.

Segundo, Michel Foucault (1988), a partir dos séculos XVIII e XIX, com a expansão do mercado e dos movimentos migratórios, que aumentaram as multiplicidades e pluralidades da população, as sociedades ocidentais teriam experimentado o surgimento dos biopoderes, isto é, de práticas de poder que se apropriaram da vida para o governo deste novo corpo social heterogêneo. Desse modo, o poder passou a investir sobre o corpo-espécie como suporte de processos biológicos 
controlados por meio de regulações, direcionadas para ajustar os fenômenos da população aos processos econômicos, funcionando como “uma bio-política da população” (FOUCAULT, 1988, p. 131).

Portanto, a biopolítica realizou uma intervenção em nível global ou populacional, mapeando os fenômenos da vida humana para estabelecer um padrão de normalidade para esta vida, a partir do qual passou a controlar as populações. Por um lado, passou a exercer o poder de fazer viver aquela parcela normalizada, e por outro lado, de deixar morrer aquela que insistia em desviar-se. Porém, em alguns momentos o poder de morte se apresentou como um complemento do poder de gerir e ampliar a vida, fazendo, e não só deixando, morrer aqueles que representavam um perigo biológico aos que devem viver, como se viu nas guerras sangrentas ocorridas a partir do século XIX, culminando inclusive com o holocausto judeu na primeira metade do século XX - foi o que Michel Foucault (1999, p. 294) chamou de racismo.

Nesse sentido, Achille Mbembe (2018, p. 5-6) explica que o biopoder é, conforme entendido por Foucault, “aquele domínio da vida sobre o qual o poder estabeleceu o controle”, e que nos países periféricos ele se concretiza dividindo as pessoas entre aquelas que devem viver e as que devem morrer, quem é descartável e quem não é, estabelecendo uma censura biológica denominada racismo (MBEMBE, 2018, p. 17). Nas palavras do autor, ainda em referência a Foucault, o racismo seria acima de tudo uma tecnologia destinada a permitir o exercício do biopoder, "este velho direito soberano de matar”, e um elemento constitutivo do poder do Estado na modernidade, ao conceder ao biopoder a faculdade de "regular a distribuição da morte e tornar possíveis as funções assassinas do Estado (MBEMBE, 2018, p. 18).

A questão é que no contexto do Estado neoliberal, o governamento das populações pelo exercício dos biopoderes tem no mercado um lugar de veridição, sendo que a própria coerção estatal e a decisão de quem vai morrer ou viver é pautada pela grade econômica. Nesse sentido, o mercado passou a constituir um lugar de verificabilidade ou falsificabilidade das práticas de governo, que, em última instância, decide sobre a vida e a morte de quem ameaça a vida da população (FOUCAULT, 2008, p. 45).

Para ilustrar essa transformação, Achille Mbembe (2018, p. 53-54) cita o exemplo da África, em que a mão de obra militar é comprada e vendida no mercado, pois existem fornecedores de violência não governamental que emprestam a países pobres exércitos compostos de soldadoscidadãos, crianças-soldados, mercenários e corsários. Nesse cenário, milícias urbanas, exércitos privados, segurança privada e exércitos de Estado concorrem pelo direito de exercer a violência ou 
matar, de se tornarem máquinas de guerra, as quais têm características de uma organização política e de uma empresa comercial.

Por interesses econômicos, essas máquinas de guerra promovem massacres, suprimindo rapidamente as vidas descartáveis, ou mutilações, despedaçando corpos e ceifando a vida lentamente, para fazer viver um certo grupo, que não é descartável. Nesse sentido, as formas contemporâneas, que assujeitam a vida ao poder da morte, reconfiguram a tradicional divisão realizada pelo biopoder, agora transformado em necropoder, entre aqueles que devem viver e aqueles que devem morrer, criando também a figura dos mortos-vivos, sendo, os dois últimos exemplos, inimigos da população (MBEMBE, 2018, p. 71). Assim, estabelece-se a normalidade do estado de exceção, apontada por Giorgio Agamben (2004), em que a suspensão de direitos para combater aquele que coloca em risco a vida da população encontra-se naturalizada.

A partir disso, é possível imaginar como se dá essa necropolítica, que se desenvolve nos Estados periféricos como o Brasil e permeia seus sistemas penais. Segundo Michel Foucault (2008), no governamento neoliberal, o dispositivo da segurança reúne um conjunto de estratégias e práticas de poder pautadas pelo mercado para a gestão dos riscos do crime. Essa gestão implica projetar e evitar os riscos do crime, para proteger a vida de certa parcela da população, bem como matar ou incapacitar aqueles que implementam tais riscos.

Assim, por meio de dados estatísticos, identifica-se quais grupos assumem o risco de praticar crimes e, consequentemente, de receber a punição, cabendo ao Estado definir quais crimes devem ser tolerados e quais devem ser punidos, preferencialmente com penas mais longas para reduzir os custos do sistema e fornecer, àqueles que devem viver, uma sensação de segurança pela morte ou incapacitação dos indivíduos considerados perigosos. Paralelamente, desloca-se para a sociedade a gestão desse risco de ocorrência do crime (GARLAND, 1997), o que se observa com o aumento de serviços de segurança privada, de milícias e organizações paramilitares, que não deixam de ser máquinas de guerra ou máquinas de morte direcionadas a eliminar o criminoso, o perigoso, o inimigo. Em síntese, em tal cenário, resta ao Estado a gestão atuarial e punitiva do crime e, à sociedade, a sua prevenção, implicando o fim do monopólio da força pelo Estado e a generalização da violência em nome do combate ao grande inimigo, ao perigoso, que pode ser o assaltante, o traficante ou quem estiver ameaçando a vida da população escolhida para viver (MBEMBE, 2017, p. 60).

Nesse sentido, Flávio Bortolozzi Jr. (2019, p. 165-167) explica que, no governamento neoliberal dos países periféricos, a biopolítica não se apresenta com uma tecnologia dedicada à maximização ou otimização da vida, "mas precisamente é acompanhada por um mecanismo para distribuição diferencial da morte”. Assim, o sistema penal não tenta punir o crime ou também prevenir 
os danos, a violência em si e seus riscos, mas se torna um mecanismo de exposição diferencial de alguns à violência, à morte ou à condição de morto-vivo, e, mediante racismo, produz as subjetividades vistas como risco ou ameaça a serem contidos ou anulados, dividindo-se a população em vidas a serem preservadas e vidas criminosas, descartáveis.

Para explicar como a necropolítica permeia o sistema penal brasileiro, Bortolozzi Jr. (2019, p. 258) afirma que as diversas violências praticadas pelo Estado contra os criminosos, na sua maioria negros, jovens e pobres, são socialmente toleradas ou até defendidas, em nome de uma artificial segurança daqueles que devem viver.

Note-se que a criação dos bancos de perfis genéticos para fins de persecução penal no Brasil só vem aperfeiçoar o dispositivo de segurança na necropolítica, fortalecendo a máquina de guerra estatal, que cria, mata ou mutila os perigosos, os que devem morrer para preservar as vidas e o patrimônio daqueles que são relevantes para o mercado.

Como se viu, a Lei n ${ }^{\text {o }}$ 13.964/2019 manteve ou agravou as violações de direitos daqueles registrados nos bancos de perfis genéticos estatais, que passaram a estar ainda mais expostos aos efeitos nefastos do estado de exceção naturalizado, principalmente quando são consideradas as condições desumanas das prisões brasileiras, que fazem convergir num único espaço a violência do Estado e das facções criminosas. Desse modo, os condenados por roubos, latrocínios e homicídios tentados ou consumados, sequestros e crimes sexuais estarão sujeitos à violência, terão sua intimidade invadida, sua integridade física desrespeitada, serão privados da presunção de inocência nos processos criminais e o estigma da pena os assombrará por boa parte da vida, fazendo com que sofram efeitos agudos da criminalização secundária promovida pelo sistema penal brasileiro. Talvez num futuro próximo, caso seja autorizada a busca familiar em bancos genéticos pela legislação brasileira, suas famílias também serão rastreadas, investigadas, vigiadas, rotuladas, discriminadas e mortas, sob o pretexto de combate ao inimigo.

Nesse sentido, é possível perceber que a implementação e ampliação dos bancos de perfis genéticos para fins de persecução penal no Brasil contribui para matar e neutralizar os que foram expostos à opressão da desigualdade racial e econômica desde os tempos coloniais, mantendo-os na circularidade dos cárceres desumanos e fortalecendo a máquina de guerra do Estado, que produzirá uma grande quantidade de cadáveres e mutilará vidas, ceifando a possibilidade de um recomeço, de uma reinvenção, criando uma multidão de mortos-vivos, invisíveis, sem nada a perder, familiarizados à violência e também dispostos a praticá-la. Nesse momento, vislumbra-se a lógica da sobrevivência, descrita por Achille Mbembe (2017, p. 145), em que matar se torna a maneira mais econômica de 
sobreviver, sendo a escolha de integrar uma máquina de guerra paraestatal, uma milícia ou uma facção criminosa, uma escolha de sobrevida.

\section{CONCLUSÃO}

Da presente pesquisa observa-se que não encontra respaldo concreto a justificativa de que as investigações se tornariam, em razão das alterações realizadas pela Lei ${ }^{0}$ 13.964/2019, mais técnicas e eficazes no Brasil, no que se refere ao uso dos bancos de perfis genéticos para fins criminais.

Primeiramente, porque a nova legislação radicalizou as violações de direitos e garantias constitucionais latentes na Lei $\mathrm{n}^{0}$ 12.654/2012, sobretudo desrespeitando o direito de não se autoincriminar e autorizando que a presunção de inocência dos cadastrados no banco seja convertida em presunção de culpa, quando seu DNA é encontrado na cena de um crime. Assim, atrofiam-se as demais teses investigativas, acelera-se a condenação, confirma-se a circularidade do cárcere e a sua função neutralizadora das classes consideradas perigosas.

Em segundo lugar, é preciso considerar que a eficácia do uso dos bancos de perfis genéticos para resolver crimes violentos ou sexuais é questionável. Segundo as pesquisas apresentadas, os custosos bancos têm servido essencialmente para resolver crimes patrimoniais, em quantidade muito aquém da esperada. Entretanto, o Ministério da Justiça e Segurança Pública (MINISTÉRIO..., 2019) sequer considera esses dados e faz publicidade de sua meta para ampliar os bancos de perfis genéticos brasileiros, incorporada pela nova lei, com base na solução de alguns poucos casos de crimes violentos que tiveram alguma repercussão.

Além disso, deve-se atentar para o fato de que a nova lei não enfrentou dilemas que vêm sendo objeto de debate em outros países, tal como a busca familiar em bancos estatais e/ou privados para resolver crimes. A possibilidade de identificar alguém que teve seu DNA encontrado na cena do crime a partir da busca de seus familiares em bancos de perfis genéticos pode incrementar significativamente as violações de garantias dos investigados e tem sido utilizada de maneira controversa em outros países. Ao que parece, o legislador brasileiro desconhece que o uso indiscriminado desse meio de prova pode cercear direitos, estigmatizando criminalmente famílias, a partir de uma biovigilância genética.

Diante disso, pode-se concluir que esses bancos contribuem essencialmente para o funcionamento da necropolítica do sistema penal brasileiro, que tem por objetivo fazer morrer ou mutilar grupos considerados perigosos para a vida da população que deve viver, de acordo com o 
mercado. Assim, os bancos de perfis genéticos, que armazenam essencialmente o perfil de pessoas condenadas por crimes violentos, são e continuarão sendo utilizados para manter neutralizadas essas pessoas, presas à circularidade do cárcere, sem possibilidade de recomeço, sujeitas às suas violências, vulneráveis à morte ou como uma multidão de mortos-vivos que só ganham visibilidade por também praticarem violência.

\section{REFERÊNCIAS}

2010 MARYLAND Code. Public Safety. Title 2 - Department of State Police. Subtitle 5 - Statewide DNA Data Base System. Section 2-502 - Statewide DNA data base system. JUSTIA US Law, [s. l.], 2010. Disponível em: https://bit.ly/3hJRPY5. Acesso em: 25 fev. 2020.

2019 TRANSPARENCY Report. Ancestry. 2019. Disponível em: https://bit.ly/2RFdt5h. Acesso em: 25 fev. 2020.

ABRAMOVAY, Pedro V.; BATISTA, Vera M. (org.). Depois do grande encarceramento. Rio de Janeiro: Revan, 2010.

AGAMBEN, Giorgio. Estado de exceção. Tradução Iraci D. Poleti. São Paulo: Boitempo, 2004.

AMANKWAA, Aaron Opoku; MCCARTNEY, Carole. The effectiveness of the UK national DNA database. Forensic Science International: Synergy, [s. l.], v. 1, p. 45-55, 2019. Disponível em: https://bit.ly/3vc5fzY. Acesso em: 7 jan. 2019.

BARATTA, Alessandro. Criminologia crítica e crítica do direito penal: introdução à sociologia do direito penal. Tradução Juarez Cirino dos Santos. 3. ed. Rio de Janeiro: Revan, 2002.

BERNASCO, Wim; KOOISTRA, Thessa. Effects of residential history on commercial robbers' crime location choices. European Journal of Criminology, [s. l.], v. 7, n. 4, p. 251-265, 2010. Disponível em: https://bit.ly/3bKJAaw. Acesso em: 26 fev. 2020.

BHATI, Avinash. Quantifying the Specific Deterrent Effects of DNA Databases. Washington, DC: National Criminal Justice Reference Service, 2010. 99 p. Disponível em: https://bit.ly/3v4Vunf. Acesso em: 27 fev. 2020.

BIEBER, Frederick R.; BRENNER, Charles H.; LAZER, David. Finding Criminals Through DNA of Their Relatives. Science, [s. l.], v. 132, p. 1.315-1.316, 2 jun. 2006. Disponível em: https://bit.ly/343lcwH. Acesso em: 23 fev. 2020.

BORTOLOZZI JR., Flávio. Resistir para re-existir: criminologia (d)e resistência e a (necro)política brasileira de drogas. Belo Horizonte: D’Plácido, 2019.

BRASIL. Câmara dos Deputados. Projeto de Lei PL 882/2019. Altera o Decreto-Lei n ${ }^{\circ} 2.848$, de 7 de dezembro de 1940 - Código Penal, o Decreto-Lei n 3.689, de 3 de outubro de 1941 - Código de 
Processo Penal, a Lei $n^{\circ} 7.210$, de 11 de julho de 1984 [...]. 2019b. Disponível em: https://bit.ly/3fb0CRn. Acesso em: 25 mar. 2020.

BRASIL. Ministério da Justiça e Segurança Pública. Rede Integrada de Bancos de Perfis Genéticos (RIBPG). XI Relatório da Rede Integrada de Bancos de Perfis Genéticos (Novembro/2019). Dados estatísticos e resultados - Mai/2019 a Nov/2019. Brasília: dezembro/2019d. Disponível em: https://bit.ly/3uazfLa. Acesso em: 6 jan. 2020.

BRASIL. Ministério da Justiça e Segurança Pública. Secretaria Nacional de Segurança Pública. Comitê Gestor da Rede Integrada de Bancos de Perfis Genéticos. Resolução nº 7, de 21 de março de 2017. Brasília, DF, Diário Oficial da União, Edição 65, Seção 1, página 173, 04/04/2017b. Disponível em: https://bit.ly/2QHunje. Acesso em: 26 mar. 2020.

BRASIL. Ministério da Justiça e Segurança Pública. Secretaria Nacional de Segurança Pública. Diretoria de Políticas de Segurança Pública. Coordenação-Geral de Pesquisa e Inovação. Coordenação da Rede Integrada de Bancos de Perfis Genéticos. Resolução $n^{0} 11$, de $1^{\circ}$ de julho de 2019. Brasília, DF, Diário Oficial da União, Edição 126, Seção 1, página 39, 03/07/2019a. Disponível em: https://bit.ly/344d9iS. Acesso em: 25 mar. 2020.

BRASIL. Ministério Extraordinário da Segurança Pública. Secretaria Nacional de Segurança Pública. Comitê Gestor da Rede Integrada de Bancos de Perfis Genéticos. RIBGP. Resolução nº 9, de 13 de abril de 2018. Brasília, DF, Diário Oficial da União, Edição 80, Seção 1, página 118, 26/04/2018. Disponível em: https://bit.ly/3wqxtat. Acesso em: 25 mar. 2020.

BRASIL. Superior Tribunal de Justiça (STJ). HC 536114 / MG. Sexta Turma. Rel. Min. Nefi Cordeiro. J. 04/02/2020. DJe, 10/02/2020. Disponível em: https://bit.ly/3oEHf69. Acesso em: 22 mar. 2020.

BRASIL. Supremo Tribunal Federal (STF). ADC 43. Plenário. Rel. Min. Marco Aurélio. J. 07/11/2019. DJe, 08/11/2019c. Disponível em: https://bit.ly/346HkWU. Acesso em: 24 mar. 2020.

BRASIL. Supremo Tribunal Federal (STF). HC 126292. Plenário. Rel. Min. Teori Zavascki. J. 02/09/2016. DJe, 06/02/2017a. Disponível em: https://bit.ly/3bIcqsc. Acesso em: 24 mar. 2020.

BRASIL. Supremo Tribunal Federal (STF). RE 973837. Plenário. Rel. Min. Gilmar Mendes. J. 24/06/16. DJe, 11/10/2016. Disponível em: https://bit.ly/2QFO5ff. Acesso em: 20 mar. 2020.

BURROWS, J.; TARLING, R. Measuring the impact of forensic science in detecting burglary and autocrime offences. Science \& Justice, [s. l.], v. 44, n. 4, p. 217-222, out. 2004. Disponível em: https://bit.ly/3oCcdfj. Acesso em: 7 mar. 2020.

CHOUKR, Fauzi H. Temas de Direito Processual Penal. Rio de Janeiro: Lumen Juris, 2004.

CODE of the District of Columbia. Title 22. Criminal Offenses and Penalties. Chapter 41B. DNA Sample Collection. § 22-4151. Qualifying offenses. D.C. Law Library, [Washington, DC], 29 jun. 2016. Disponível em: https://bit.ly/3fDZ5Ca. Acesso em: 25 fev. 2020. 
CROSS, Theodore P. et al. Biological Evidence in Adult and Adolescent Sexual Assault Cases: Timing and Relationship to Arrest. Journal of interpersonal violence, [s. l.], v. 35, n. 7-8, p. 1.828-1.839, 2020. Disponível em: https://bit.ly/3wlZjon. Acesso em: 10 fev. 2020.

DAVIS, Ben. What was the FBI originally formed to do? Mvorganizing.org, [s. l.], March 6, 2021. Disponível em: https://bit.ly/2Wbqoy6. Acesso em: 21 maio 2021.

DOLEAC, Jennifer L. The Effects of DNA Databases on Crime. American Economic Journal: Applied Economics, [s. l.], v. 9, n. 1, p. 165-201, jan. 2017. Disponível em: https://bit.ly/3uabJOL. Acesso em: 10 fev. 2020.

EUROPEAN COURT OF HUMAN RIGHTS. Grand Chamber. Case of S. and Marper v. the United Kingdom (Applications nos. 30562/04 and 30566/04). Strasboug, 4 Dec. 2008. Disponível em: https://bit.ly/346Hhdy. Acesso em: 10 mar. 2020.

FAMILYTREEDNA Privacy Statement. 5 jul. 2019. Disponível em: https://bit.ly/3wqYoCW. Acesso em: 25 fev. 2020.

FARRINGTON, David P. et al. The concentration of offenders in families, and family criminality in the prediction of boys' delinquency. Journal of Adolescence, [s. l.], v. 24, n. 5, p. 579-596, out. 2001.

FOUCAULT, Michel. Em Defesa da Sociedade. Curso no Collège de France (1975-1976). Tradução Maria Ermantina Galvão. São Paulo: Martins Fontes, 1999.

FOUCAULT, Michel. História da sexualidade. I. A vontade de saber. Tradução Maria Thereza da Costa Albuquerque e J. A. Guilhon Albuquerque. 13. ed. Rio de Janeiro: Graal, 1988.

FOUCAULT, Michel. Nascimento da Biopolítica. Curso dado no Collège de France (1978-1979). Tradução Eduardo Brandão. São Paulo: Martins Fontes, 2008.

FOUCAULT, Michel. Os anormais. Curso no Collège de France (1974-1975). Tradução Eduardo Brandão. São Paulo: Martins Fontes, 2001.

GARCÍA, Óscar; CRESPILLO, Manuel; YURREBASO, Iñaki. Identificación de sospechosos a través de búsquedas familiares en la base de datos de ADN de interés criminal. Implicaciones sociales, éticas y científicas. Revista Española de Medicina Legal, [s. l.], v. 43, n. 1, p. 26-34, jan./mar. 2017.

GARLAND, David. 'Governmentality’ and the Problem of Crime: Foucault, Criminology, Sociology. Theoretical criminology, [s. l.], v. 1, n. 2, p. 173-214, 1997.

GEDMATCH.COM Terms of Service and Privacy Policy. 9 dez. 2019. Disponível em: https://bit.ly/3wokFRP. Acesso em: 26 fev. 2020.

HENNING, Anna C. Compulsory DNA Collection: A Fourth Amendment Analysis. CRS Report for Congress. Prepared for Members and Committees of Congress. Congressional Research Service, [Washington, DC], 16 fev. 2010. Disponível em: https://bit.ly/3v9N5z3. Acesso em: 23 mar. 2020. 
MAGUIRE, Christopher N. et al. Familial searching: A specialist forensic DNA profiling service utilising the National DNA Database ${ }^{\circledR}$ to identify unknown offenders via their relatives-The UK experience. Forensic Science International Genetics, [s. l.], v. 8, n. 1, p. 1-9, 1 jan. 2014. Disponível em: https://bit.ly/3fzSdWB. Acesso em: 3 fev. 2020.

MBEMBE, Achille. Necropolítica. Biopoder, soberania, estado de exceção, política de morte. Tradução Renata Santini. São Paulo: N-1, 2018.

MBEMBE, Achille. Políticas da inimizade. Tradução Marta Lança. Lisboa: Antígona, 2017.

MCCARTNEY, Carole. The DNA Expansion Programme and Criminal Investigation. The British Journal of Criminology, [s. l.], v. 46, n. 2, p. 175-192, mar. 2006. Disponível em: https://bit.ly/3oEIa6B. Acesso em: 12 abr. 2020.

MINISTÉRIO da Justiça anuncia meta superada e coleta o DNA de 67 mil presos condenados. Brasília, Ministério da Justiça e Segurança Pública, 5 dez. 2019. Disponível em: https://bit.ly/3bMeRK3. Acesso em: 3 mar. 2020.

MORAES, Maurício Zanoide de. Presunção de inocência no processo penal brasileiro: análise de sua estrutura normativa para a elaboração legislativa e para a decisão judicial. Rio de Janeiro: Lumen Juris, 2010.

NARAYAN, Chandrika. 'Grim Sleeper' killer sentenced to death. CNN, [s. l.], August 10, 2016. Disponível em: https://cnn.it/3bLcGGK. Acesso em: 24 fev. 2020.

PAVARINI, Massimo; GIAMBERARDINO, André. Curso de penologia e execução penal. São Paulo: Tirant Brasil, 2018.

POLÍTICA de privacidade do MyHeritage. 26 jan. 2020. Disponível em: https://bit.ly/3vaqBO5. Acesso em: 25 fev. 2020.

PRIVACY Highlights. 23andMe. Last Updated: October 30, 2020. Disponível em: https://bit.ly/3bMyRfD. Acesso em: 21 maio 2021.

QUEIJO, Maria E. Coleta de material genético e identificação criminal: a Lei n. 12654/2012 prestase a restringir o princípio “nemo tenetur se detegere”? In: SCHIOCCHET, Taysa; GARRIDO, Rodrigo Grazinoli (org.). Bancos de perfis genéticos para fins de persecução criminal: práticas periciais e impactos jurídico-sociais (I). Rio de Janeiro: Multifoco, 2018. p. 227-244.

ROBBINS, Rebecca. The Golden State Killer Case Was Cracked with a Genealogy Web Site. Scientific American, [s. l.], April 28, 2018. STAT. Policy \& Ethics. Disponível em: https://bit.ly/3hKeEuX. Acesso em: 25 fev. 2020.

ROHLFS, Rori V. et al. Correction: The Influence of Relatives on the Efficiency and Error Rate of Familial Searching. PLoS ONE, [s. l.], v. 9, n. 1, 6 jan. 2014. Disponível em: https://bit.ly/3bNfXp7. Acesso em: 25 fev. 2020. 
ROMAN, John K. et al. The DNA field experiment: a randomized trial of the cost-effectiveness of using DNA to solve property crimes. Journal of Experimental Criminology, [s. l.], v. 5, p. 345369, 2009. Disponível em: https://bit.ly/348GMQa. Acesso em: 10 jan. 2020.

ROWE, David C.; FARRINGTON, David P. The Familial Transmission of Criminal Convictions. Criminology, [s. l.], v. 35, n. 1, p. 177-201, fev. 1997.

SARLET, Ingo W. Proteção da personalidade no ambiente digital: uma análise à luz do caso do assim chamado Direito ao Esquecimento no Brasil. Espaço Jurídico Journal of Law [EJJL], [s. l.], v. 19, n. 2, p. 491-530, 2018. Disponível em: https://bit.ly/2QHw1Bq. Acesso em: 20 mar. 2020.

SCHIOCCHET, Taysa. O humano entre o direito e a genética: pressupostos para o debate legislativo acerca das implicações jurídicas concernentes à criação de bancos de perfis genéticos para fins criminais no Brasil. In: SCHIOCCHET, Taysa (org.). Bancos de Perfis Genéticos para Fins de Persecução Criminal: Análise Interdisciplinar e em Direito Comparado. Rio de Janeiro: Multifoco, 2015. p. 29-60.

SCHIOCCHET, Taysa. Reflexões jurídicas acerca da regulamentação dos bancos de perfis genéticos para fins de investigação criminal no Brasil. In: MACHADO, Helena; MONIZ, Helena (org.). Bases de dados genéticos forenses. Tecnologias de controlo e ordem social. Coimbra: Coimbra Editora, 2014. p. 67-102.

SIZE of global databases. DNAResource. Forensic DNA Policy. 2019. Disponível em: https://bit.ly/3yrGLou. Acesso em: 6 jan. 2019.

THE DNA Expansion Programme: reporting real achievement? GeneWatch UK Briefing. February 2006. Disponível em: https://bit.ly/3f9iUSP. Acesso em: 2 abr. 2020.

TRACY, Paul E.; MORGAN, Vincent. Big Brother and His Science Kit: DNA Databases for $21^{\text {st }}$ Century Crime Control? The Journal of Criminal Law and Criminology, [s. l.], v. 90, n. 2, p. 635-690, 2000. doi:10.2307/1144232. Disponível em: https://bit.ly/343hWBi. Acesso em: 31 mar. 2020.

UNITED KINGDOM. National DNA Database Strategy Board Biennial Report 2018 - 2020. 2020. Disponível em: https://bit.ly/2XJbDTE. Acesso em: 21 maio 2021.

UNITED STATES. 42 U.S.C. 14132 - Index to facilitate law enforcement exchange of DNA identification information. 2008. Disponível em: https://bit.ly/3vccIzd. Acesso em: 31 mar. 2020.

UNITED STATES. Department of Justice. Bureau of Justice Statistics. Correctional Populations in the United States, 1996. Washington, DC: Bureau of Justice Statistics, April 1999. Disponível em: https://bit.ly/3oH81em. Acesso em: 23 fev. 2020.

UNITED STATES. Federal Bureau of Investigation (FBI). CODIS - NDIS Statistics. Washington, DC, February, 2020a. Disponível em: https://bit.ly/3ucP8km. Acesso em: 31 mar. 2020.

UNITED STATES. Federal Bureau of Investigation (FBI). Combined DNA Index System (CODIS). Washington, DC, 2020b. Disponível em: https://bit.ly/3bNd9rV. Acesso em: 31 mar. 2020. 
UNITED STATES. Federal Bureau of Investigation (FBI). SWGDAM Recommendations to the FBI Director on the "Interim Plan for the Release of Information in the Event of a 'Partial Match’ at NDIS”. Forensic Science Communications, October 2009 - v. 11 - n. 4. Disponível em: https://bit.ly/3uiMc65. Acesso em: 1 abr. 2020.

UNITED STATES. H.R.4614 - Katie Sepich Enhanced DNA Collection Act of 2010. 2010. Disponível em: https://bit.ly/3bL7liu. Acesso em: 31 mar. 2020.

UTILIZING DNA Technology to Solve Cold Cases Act of 2010. 111th Congress 2d Session. H. R. 6011. To direct the Attorney General to design and implement a procedure to permit enhanced searches of the National DNA Index System. In the House of Representatives July 30, 2010. Mr. Schiff introduced the following bill; which was referred to the Committee on the Judiciary. Disponível em: https://bit.ly/3bLdpaW. Acesso em: 24 fev. 2020.

WALLACE, Helen. Expanding the UK DNA Database: impacts on crime, trust and human rights. In: SCHIOCCHET, Taysa (org.). Bancos de Perfis Genéticos para Fins de Persecução Criminal: Análise Interdisciplinar e em Direito Comparado. Rio de Janeiro: Multifoco, 2015. p. 83-100.

ZAFFARONI; Eugenio Raúl et al. Direito Penal Brasileiro - I. Rio de Janeiro: Revan, 2006.

ZAFFARONI; Eugenio Raúl. O inimigo no direito penal. Tradução Sérgio Lamarão. 2. ed. Rio de Janeiro: Revan, 2007.

ZEDLEWSKI, Edwin; MURPHY, Mary B. DNA Analysis for "Minor” Crimes: A Major Benefit for Law Enforcement. National Institute of Justice Journal, Washington, DC, n. 253, p. 2-5, jan. 2006. Disponível em: https://bit.ly/3u4RZf7. Acesso em: 30 mar. 2020. 